\title{
Improving water resources management in the irrigated zone of the Aral Sea region
}

\author{
Bakhtiyar Matyakubov ${ }^{1 *}$, Rashit Koshekov ${ }^{2}$, Meili Avlakulov ${ }^{3}$, and Bakhtiyar Shakirov ${ }^{4}$ \\ ${ }^{1}$ Tashkent Institute of Irrigation and Agricultural Mechanization Engineers, Tashkent, Uzbekistan \\ ${ }^{2}$ Nukus branch of Tashkent State Agrarian University, Karakalpakstan, Uzbekistan \\ ${ }^{3}$ Karshi Engineering and Economics Institute, Karshi, Uzbekistan \\ ${ }^{4}$ Andijan branch of Tashkent State Agrarian University, Andijan, Uzbekistan
}

\begin{abstract}
One of the most important objectives in the world is to improve rational water resources management methods. In this regard, the rational management of water resources and optimal water resources distribution, especially on on-farm systems, are considered very important. In this direction, given the negative consequences that have developed over the past more than 40 years in the lower reaches of the Amu Darya River, the need to improve the methods of effective management of water resources in the Aral Sea basin is urgent.
\end{abstract}

\section{Introduction}

The state of irrigation systems, water use, organizational and structural forms of water use management are analyzed; it should be noted that, in the existing irrigation contour of the Republic of Karakalpakstan, $22101.4 \mathrm{~km}$ of irrigation network of various levels are currently functioning. Of these, $861.8 \mathrm{~km}$ are main canals, and 2733.4 are inter-farm canals on the balance of water management organizations financed from the state budget.

Relevance of the problem. It was found that due to a steady decrease in the water level of the Amu Darya river, the head discharge of large canals significantly decreased with a corresponding change in hydraulic and hydrodynamic parameters in the living section of the Kyzketken-Kegeili, Kuvansh-Jarma, and others canals, accompanied by intensive siltation of their channel along the entire length. Due to the siltation of the channel, the throughput of individual canals decreased by $30-35 \%$ compared to the design flow rate. The actual value $B / h_{\text {average }}$ reached 28-51.8 with the optimal 16-18. As a result of the channel siltation, the bottom of all the channels rose, and the actual value $B / h_{\text {average }}$ reached 28 51.8 with the optimal 16-18. As a result of the channel siltation, the bottom of all the channels rose, and the actual value.

A decrease in depth is accompanied by lateral erosion. In many places, a significant part of the dams is washed out, and with a slight rise in the water horizon, an emergency situation is created. The Kuvanysh-Jarma and Kyzketken-Kegeili canals are in the best position, where $92 \%$ and $79.1 \%$ of their length, respectively, are in a satisfactory technical

\footnotetext{
*Corresponding author: b.matyakubov@tiiame.uz
} 
condition. These indicators are rather low along the Pakhtaarna - Naiman and Mangit Nazarkhan canals and amount to $53 \%$ and $57 \%$ of the surveyed channel length, respectively. Water resources management, efficient use of irrigation water in the irrigated area as well as changes in hydraulic and hydrodynamic parameters in the living section of the canal have been worked on by many scientists, such as Balla D., Hamidov A., Khamidov M., Bazarov D., Uralov B., Matyakubov B., Vokhidov O., Koshekov R.M, Ramazanov A., Raxmatov N., Xidirov S., Bakiev M., etc. [1-20].

At the modern technical level and the state of the irrigation systems of the studied object of study, the organization of water use, large water losses are observed, especially for filtration, evaporation during the transportation of irrigation water through the main and inter-farm canals from the place of intake to the points of water distribution of the economy - water consumers. In general, in the Republic of Karakalpakstan, the volume of unproductively consumed water in some years reached 3.7 billion $/ \mathrm{m} 3$, or $46 \%$ of the total water intake. From the point of water intake from the Amu Darya River and its transportation to the border of the administrative districts, up to $9 \%$ is irretrievably lost, from the border of the district to the border of the economy up to $16 \%$ and on the on-farm irrigation network - 29\% delivered to the water consumer [21-30].

\section{Methods}

The studies were carried out according to the traditional method of carrying out field studies of structures. Levels, theodolite, hydrometric vertices, Chipoletti water measuring devices, and attack measuring instruments were used to research in the field. Photographs from the Google site and canal management materials were also used to assess the technical condition of irrigation networks.

\section{Results and Discussion}

In the Republic of Karakalpagistan, on-farm irrigation ditches with a length of $18,510 \mathrm{~km}$ are in the sphere of influence of the Association of Water Consumers, which are operated at the expense of farmers and other farms. Of these, only $19 \mathrm{~km}$ (the Kuvanysh - Jarma, and Pakhtaarna - Naiman irrigation systems) have a concrete lining, and $102 \mathrm{~km}$ consist of reinforced concrete trays (the Pakhtaarna - Naiman, Mangit - Nazarkhan, Kattagar Bozatau irrigation systems). In the context of the zone of command of irrigation systems, the specific length of the on-farm network ranges from 24.1 linear meters/hectare up to 52 linear meters/hectare with an average in the Republic of 37 linear meters/hectare. The study results and calculations indicate an increase in the volume of water losses in on-farm canals as their specific length increases. This causes an increase in the head water intake for the system as a whole, the volume of operating costs, and, accordingly, an increase in the cost of water supplied to farmers and other water users.

The efficiency factor (COP) of main canals is 0.90 , inter-farm - 0.84, on-farm network 0.71 , and on average for the system - 0.54 . Sufficiently high efficiency of main and interfarm canals, the overwhelming majority of which have an earthen bed, is due to the presence of "lenses" from ground and infiltration waters, which during their operation merge with the filtration flow from the canal beds. Due to the formation of the "supported filtration" mode, the volume of losses decreases sharply, significantly affecting their efficiency. A similar situation is observed along the route of the on-farm irrigation network, the efficiency of which, on average, for irrigation systems is 0.71 . Nevertheless, almost $1 / 3$ of the volume of water allocated to a water consumer is lost irretrievably and does not participate in forming an indicator characterizing water productivity (Table 1). 
Table 1. The volume of losses during the transportation of water from the intake from the source to the water user

\begin{tabular}{|c|c|c|c|c|}
\hline \multirow{2}{*}{ № } & \multirow{2}{*}{$\begin{array}{c}\text { Transportation boundaries } \\
\text { water }\end{array}$} & \multirow{2}{*}{$\begin{array}{l}\text { Flow volume, } \\
\text { million } . \mathrm{m}^{3}\end{array}$} & \multicolumn{2}{|c|}{ Loss volume } \\
\hline & & & $\begin{array}{c}\text { million. } \\
\mathrm{m}^{3}\end{array}$ & $\%$ \\
\hline 1 & Water intake from the source & 8064 & - & - \\
\hline 2 & Water intake at the border of the district & 7258 & 806 & 9 \\
\hline 3 & Water intake at the border of the farm & 6100 & 1158 & 16 \\
\hline 4 & $\begin{array}{c}\text { Water intake at points of } \\
\text { water distribution of the economy }\end{array}$ & 4331 & 1769 & 21 \\
\hline & Total loss & & 3733 & 46 \\
\hline
\end{tabular}

Observations carried out in different parts of the irrigated zone revealed significant shortcomings in the organization and use of water during the non-growing and growing seasons. Due to this and other reasons of an organizational and managerial nature in production practice, there is an excess or shortage of the allocated volume of the limit during the year. Analysis of the materials of operating organizations showed that for the period 1997-2019. The volume of the allocated water limit as a whole in the Republic increased from 8028.0 million $\mathrm{m}^{3}$ to 8335.2 million $\mathrm{m}^{3}$. (Table 2 and Table 3 ). Actual water withdrawal amounted to $93.0-94.0 \%$, with almost no change from the established limit.

Table 2. Actual water withdrawal non-growing season

\begin{tabular}{|c|c|c|c|c|c|c|c|c|}
\hline 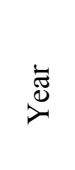 & 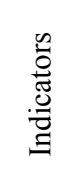 & $\begin{array}{l}\dot{0} \\
\overline{0} \\
\dot{0} \\
0\end{array}$ & $\begin{array}{l}\dot{\bar{\nu}} \\
\text { है } \\
\text { ठे } \\
z\end{array}$ & $\begin{array}{l}\dot{\bar{\nu}} \\
\text { हू. } \\
\text { صू }\end{array}$ & $\begin{array}{l}\vec{E} \\
\stackrel{\vec{E}}{\Xi} \\
\stackrel{\Xi}{=}\end{array}$ & 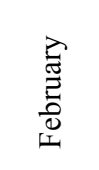 & 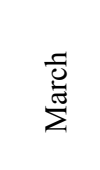 & 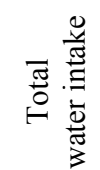 \\
\hline \multirow{2}{*}{1997} & limit & 101.56 & 361.84 & 383.62 & 64.59 & 193.12 & 773.27 & 1878.0 \\
\hline & fact & 32.58 & 251.4 & 564.71 & 240.55 & 194.37 & 594.18 & 1877.83 \\
\hline \multirow{2}{*}{2019} & limit & 82.9 & 272.2 & 259.2 & - & 267.8 & 622.0 & 1500 \\
\hline & fact & 133.0 & 271.65 & 287.42 & 292.61 & 252.94 & 281.07 & 1450.0 \\
\hline
\end{tabular}

Table 3. Actual withdrawal of the growing season

\begin{tabular}{|c|c|c|c|c|c|c|c|c|}
\hline$\stackrel{\bar{\Xi}}{\stackrel{\nu}{0}}$ & 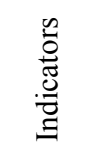 & $\begin{array}{l}\overline{0} \\
\overline{0} \\
\overline{0} \\
0\end{array}$ & $\begin{array}{l}\dot{\bar{\Xi}} \\
\text { है } \\
\text { ठे } \\
\text { z }\end{array}$ & 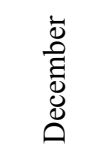 & 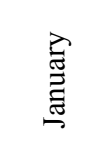 & $\begin{array}{l}\vec{E} \\
\overrightarrow{0} \\
0 \\
0 \\
0\end{array}$ & $\begin{array}{l}\frac{\pi}{0} \\
\text { 䒕 }\end{array}$ & 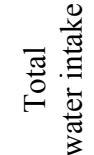 \\
\hline \multirow{2}{*}{1997} & limit* & 101.56 & 361.84 & 383.62 & 64.59 & 193.12 & 773.27 & 1878.0 \\
\hline & fact & 32.58 & 251.4 & 564.71 & 240.55 & 194.37 & 594.18 & 1877.83 \\
\hline \multirow{2}{*}{2019} & limit & 82.9 & 272.2 & 259.2 & - & 267.8 & 622.0 & 1500 \\
\hline & fact & 133.0 & 271.65 & 287.42 & 292.61 & 252.94 & 281.07 & 1450.0 \\
\hline
\end{tabular}

*-limit - the limit of water use, the established norm of water consumption

Due to the low efficiency of irrigation systems, especially the on-farm network, there is a lack of proper control over the actual water intake from the source (inter-farm canals) and water consumption. Moreover, frequent overflows of water in excess of the established limit, violations in the organization and implementation of flushing (in the non-growing season), vegetation irrigation, and specific water consumption of irrigated agriculture in the Republic is quite high.

As a result of the consistent denationalization of state farms, the liquidation of collective farms and shirkat farms, a new form of organization of agricultural production was formed 
- farms and dekhkans. Currently, they produce more than $90 \%$ of crop and livestock products in the Republic. The formation of farms as an independent structure for organizing and conducting agricultural production with the corresponding rights and obligations to the state necessitated revising the existing procedure and conditions for water use, conducting repair and restoration work on the irrigation and irrigation drainage network.

The main task of the Association of Water Consumers is the rational use of available water resources, increasing the productivity of irrigated lands, protecting the rights of water consumers, and representing their interests in government bodies and organizations. The Water Consumer Associations were created in the Republic of Karakalpakstan with a total serviced area of 362.0 thousand hectares, unites 7985 members, of which 7852 are farms. As WUAs were created, the vast majority of on-farm infrastructures were transferred to the balance of associations. The legal basis for the relationship between water users, WUA "Shokh-aryk" and the Department of Irrigation Systems Kyzketken-Kegeili are contractual relations and timely filing of a water application. Water resources management on the example of WUA "Shokh-aryk" is carried out according to the following scheme (Fig. 1).

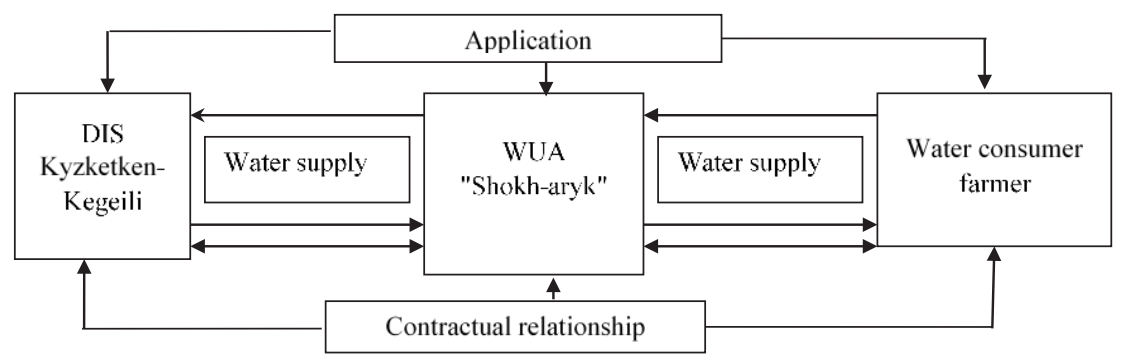

Fig. 1. Water resources management scheme on the example of WUA "Shokh Aryk"

The analysis of WUA activities, in general, indicates their effectiveness in water resources management. At the same time, their creation, according to the administrative-territorial principle, has shortcomings in the organization of water use. In most cases, the volume of the annually allocated limit is not brought to the attention of water consumers, there is no water use plan for the non-growing and growing seasons, water is unevenly distributed between farms, dekhkans, and other farms, and the rights of water consumers located in the lower parts of the water supply canals are infringed. Due to the existing uncertainty in financing and material and technical supply sources, the procedure for carrying out repair and restoration and operational work is somewhat complicated.

Due to the timely conclusion of contractual agreements and applications for water supply with the Kyzketken-Kegeili WUA, a generally satisfactory and fairly stable level of water supply to the Shokh-aryk WUA was achieved within the established limit, so in 2005-2007, for the hydrological year, it was $98-99 \%$, during the non-growing season 95 $99 \%$, and during the growing season $98-99 \%$ (Table 4 ).

The actual volume of used water as a whole does not exceed the allocated limit, which is very important from the point of view of streamlining the management of available water resources in the Republic. 
Table 4. Availability of contractual agreements and applications for water under various water resources management schemes

\begin{tabular}{|c|c|c|c|c|c|}
\hline \multirow{2}{*}{ Control circuit } & \multicolumn{4}{|c|}{ Number of water consumers } \\
\cline { 2 - 6 } & $\begin{array}{c}\text { Total, } \\
\text { units }\end{array}$ & \multicolumn{2}{|c|}{ Contracts concluded } & \multicolumn{2}{|c|}{$\begin{array}{c}\text { Applications } \\
\text { submitted }\end{array}$} \\
\cline { 3 - 6 } & & PCS** & $\%$ & PCS. & $\%$ \\
\hline $\begin{array}{c}\text { Administrative-territorial } \\
\text { (WUA "Suushy ") }\end{array}$ & 116 & 81 & 70 & 46 & 40 \\
\hline $\begin{array}{c}\text { Hydrographic (WUA } \\
\text { " Shokh -aryk") }\end{array}$ & 26 & 26 & $\begin{array}{c}\text { one } \\
\text { hundred }\end{array}$ & 26 & $\begin{array}{c}\text { one } \\
\text { hundred }\end{array}$ \\
\hline
\end{tabular}

** - pieces

Due to the timely conclusion of contractual agreements and applications for water supply with the WUA Kyzketken-Kegeili, a generally satisfactory and fairly stable level of water supply to the Shokh-aryk WUA was achieved within the established limit, so in 2005-2007. In the hydrological year, it was $98-99 \%$, in the non-growing season $95-99 \%$, and in the growing season $98-99 \%$. The actual volume of used water as a whole does not exceed the allocated limit, which is very important from the point of view of streamlining the management of available water resources in the Republic.

The observation results with a systematic account of the volume of water allocated by the limit between water users indicate a relatively uniform distribution of it, regardless of the distance of the location of the territory of farms (dekhkan farms) from the irrigation source. So, under the administrative-territorial management scheme, the level of water supply to water consumers located in the upper part of the source (along the length of the canal) was $97-100 \%$, and in the lower part did not exceed $80 \%$. With the hydrographic distribution scheme of the allocated limit, the level of water availability is practically the same along the length of the canal (Table 5).

Since under the administrative-territorial principle of management, the level of water supply to water consumers located in the upper parts of the source (along the length of the canals) was $97-100 \%$, and in the lower part did not exceed $80 \%$. Under the hydrographic principle of distribution of the water limit, the level of water supply is practically the same along the length channel.

Table 5. The level of water supply for farms, depending on the individual source (along the length of the canal)

\begin{tabular}{|c|c|c|c|c|c|}
\hline \multirow{2}{*}{ № } & \multirow{2}{*}{$\begin{array}{c}\text { Number } \\
\text { of farm } \\
\text { farms, units }\end{array}$} & $\begin{array}{c}\text { Location along } \\
\text { the length of } \\
\text { the channel } \\
\text { (water source) }\end{array}$ & $\begin{array}{c}\text { Irrigation- } \\
\text { Mayaplo- } \\
\text { Schad, ha }\end{array}$ & $\begin{array}{c}\text { At the } \\
\text { administrative- } \\
\text { territorial } \\
\text { administration }\end{array}$ & $\begin{array}{c}\text { With a } \\
\text { hydrographic } \\
\text { control scheme }\end{array}$ \\
\hline 1 & 10 & Upper & 525 & $97 \ldots 100$ & $95 \ldots 100$ \\
\hline 2 & 11 & Srenya & 564.3 & $95 \ldots 100$ & $94 \ldots 100$ \\
\hline 3 & 5 & Lower & 240 & $74 \ldots 80$ & $93 \ldots 100$ \\
\hline
\end{tabular}

\section{Conclusions}

1. At present, more than $30 \%$ of the existing main and inter-farm canals require repair and restoration work (reconstruction, mechanical cleaning, repair). At the current level of technical condition and operation of irrigation systems, irreversible losses of a large volume 
of water from the channel of irrigation canals of various orders occur, which ultimately affects the productivity of the water limit allocated for the Republic.

2. The formation of farms as an independent structure for the organization and conduct of agricultural production with the appropriate rights and responsibilities has necessitated the creation of water consumer associations to regulate water relations in farms. When managing the available water resources within the framework of the water consumers association, real prerequisites are created for the purposeful use of the volume of water allocated to each farm according to the limit.

3. Creating an association of water consumers based on the hydrographic principle significantly improves the management of available water resources, increases its productivity, protects the rights of water consumers, and represents their interests in government agencies and organizations. When organizing the management of available water resources according to the hydrographic principle, real conditions are created for the prompt and uniform distribution of the water limit allocated at the request without infringing on the rights of water consumers.

\section{References}

1. Balla D, Omar M, Maassen S, Hamidov A, Khamidov M. Efficiency of duckweed (Lemnaceae) for the desalination and treatment of agricultural drainage water in detention reservoirs, Environmental Science and Engineering (Subseries: Environmental Science), pp.423-440, (2014)

2. Bazarov D., Uralov B., Matyakubov B., Vokhidov O., Uljaev F., Akhmadi M. The effects of morphometric elements of the channel on hydraulic resistance of machine channels of pumping stations, IOP Conference Series: Materials Science and Engineering, (2020)

3. Matyakubov B., Begmatov I., Raimova I. and Teplova G. Factors for the efficient use of water distribution facilities. IOP Conf. Ser. Mater. Sci. Eng. 883, 012025 (2020).

4. Koshekov R.M. Rational use of water resources and improvement of the reclamation state of irrigated lands in the Republic of Karakalpakstan in conditions of low water, Nukus. Science publishing house, p.172, (2018)

5. Mamajonov M., Bazarov D., Uralov B., Rakhmatov N., Djumabaeva G. The impact of hydro-wear parts of pumps for operational efficiency of the pumping station, Journal of Physics: Conference Series. (2019),

6. Marupov I., Imomov S., Ermatova D., Majitov J., Kholikova N., Tagaev V., Nuritov I. Research of vertical forces for acting tractor unit, IOP Conference Series: Earth and Environmental Science, 614, (2020)

7. Matyakubov B. How efficient irrigation can ensure water supply in the Lower Amudarya basin of Uzbekistan, International Water and Irrigation, 23(3), pp. 26-27, (2003)

8. Matyakubov B., Mamazhonov M., Teplova G, Shakirov B., Shakirov B. Forebays of the poligonal cross - section of the irrigating pumping station, IOP Conf. Series: Materials Science and Engineering 883, 012050, (2020), doi:10.1088/1757899X/883/1/012050

9. Ibraymov A., Bakiev M., Kodirov O., Raxmatov N., Ibragimova S. Gis Application in Water Resource Management in Uzbekistan, International Journal of Recent Technology and Engineering (IJRTE), 8(6), pp. 5850-5854, (2020) 
10. Imomov S., Shodiev E., Tagaev V., Qayumov T. Economic and statistical methods of frequency maintenance of biogas plants, IOP Conference Series: Materials Science and Engineering, 883 (1), (2020)

11. Bazarov D., Markova I., Raimova I., Sultanov Sh. Water flow motion in the vehicle of main channels. IOP Conf. Ser. Mater. Sci. Eng. 883, 012025 (2020).

12. Ramazanov A., Buriev S. and Koshekov R. Water availability and water use planning in Aral Sea basing, IOP Conf. Series. Materials Science and Enjenering 883, (2020)

13. Raxmatov N., Maksudova L., Ashirov B., Jamalov F., Tajieva D. The concept of creating a new water management system in the region, IOP Publishing, IOP Conf. Series: Materials Science and Engineering 869 (2020) 072014., doi:10.1088 / 1757 899X /869/7/072014.

14. Krutov A., Norkulov B., Uljaev F., and Jamalov F. Results of a numerical study of currents in the vicinity of a damless water intake. IOP Conf. Ser. Mater. Sci. Eng. 1030, 012121 (2021).

15. Raxmatov N., Artykbekova F., Uljaev F., Sapaeva M., Nazaraliev D., Jumanov O. "Improving the efficiency of lead exploitation pumping station channels, IOP Publishing, IOP Conf. Series: Materials Science and Engineering 869 (2020) 072014, doi:10.1088 / 1757 - 899X /869/7/072014

16. Krutov A., Choriev R., Norkulov B., Mavlyanova D. and Shomurodov A. Mathematical modelling of bottom deformations in the kinematic wave approximation. IOP Conf. Ser. Mater. Sci. Eng. 1030, 012147 (2021).

17. Khamidov F., Imomov S., Abdisamatov O., Sarimsaqov M., Ibragimova G., Kurbonova K. Optimization of agricultural lands in land equipment projects, Journal of Critical Reviews, 7 (11), pp. 1021-1023, (2020)

18. Khamidov M., Khamraev K., Isabaev K. Innovative soil leaching technology: A case study from Bukhara region of Uzbekistan, IOP Conference Series: Earth and Environmental Science, 422(1), 012118, (2020)

19. Kozlov D., Ghebrehiwot A. Integrated design and construction approach to hydrotechnical structures in Eritrea IOP Conference Series: Materials Science and Engineering, 2020, 869(7), 072012

20. Khamidov M., Khamraev K., Azizov S., Akhmedjanova G. Water saving technology for leaching salinity of irrigated lands: A case study from Bukhara region of Uzbekistan, Journal of Critical Reviews, 7(1), pp.499-509, (2020)

21. Kozlov D., Yurchenko A. The role of inspection of hydraulic structures in the assessment of their technical condition, IOP Conference Series: Materials Science and Engineering, 883(1), 012049, (2020)

22. Hamidov A., Khamidov M., Ishchanov J. Impact of climate change on groundwater management in the northwestern part of Uzbekistan, 10(8), Agronomy, (2020)

23. Vafoev R., Vafoev S., Akhmedov S., Imomov S. Method for sealing ground in trench closed drain, IOP Conference Series: Earth and Environmental Science, 614(1), (2020)

24. Bednaruk S.E., Chukanov V.V., Klenov E.M., Kozlov D.V. Accounting for the Thermal State of the Sayano-Shushenskaya Dam to Determine the Safe Maximum Water Levels in the Reservoir in Developing Its Dispatch Schedules, Power Technology and Engineering, 54(4), pp. 451-455, (2020)

25. Uralov B., Xidirov S., Matyakubov B., Eshonkulov Z., Norkulov B., Gayur A. River channel deformations in the area of damless water intake, IOP Publishing, IOP Conf. 
Series: Materials Science and Engineering 869 (2020) 072014., doi:10.1088/1757899X/869/7/07201

26. Anghesom A. Ghebrehiwot, Kozlov D.V. Spatial and Statistical Variability Analyses of Satellite-Based Climatic Data in Mereb-Gash Basin, Water Resources, 48(1), pp. 146-157, (2021)

27. Uralov B., Rakhmatov N., Khidirov S., Safarov G., Uljaev F., Raimova I. Hydraulic modes of damless water intake, IOP Conf. Series: Materials Science and Engineering 1030 (2021), 012123, doi:10.1088/1757-899X/1030/1/012123

28. Kozlov D.V., Kuleshov S.L. Multidimensional Data Analysis in the Assessment of Ice-Jam Formation in River Basins, Water Resources, 46(2), pp. 152-159, (2019)

29. Krutov A., Norkulov B., Mavlyanova D. Simulation of spreading of non-conservative passive substances in water bodies. IOP Conf. Ser. Mater. Sci. Eng. 883(1), 012028 (2020)

30. Krutov A., Norkulov B., Artikbekova F., Nurmatov P. Optimal location of an intake at a reservoir prone to salt diffusion. IOP Conf. Ser. Mater. Sci. Eng. 869(7), 072020, (2020) 